\title{
The Energy Leviathan: or how U.S. Shales and Brazil Biodiesel Governance Systems Fail to Promote Decentralization, Accountability, Equity, and Society Participation
}

\author{
Arnoldo de Lima ${ }^{1}$, Fabiano Toni ${ }^{2}$
}

\begin{abstract}
Energy resources and their different forms of regulation are critical to sustainable development. Given this perspective, we compare two different energy resources and their governance systems the Eagle Ford Shale in the U.S. and the Gaucho Biodiesel Pole in Brazil. Despite the differences in terms of the nature of the energy resource, stakeholders, and institutions, both systems perform poorly in terms of governance, defined here as equity, participation, transparency, and accountability. We collected data using semi-structured interviews with stakeholders, participated in public hearings, and archival research. We found patterns that reveal asymmetric power relations amongst stakeholders and institutions, especially the dominance of the energy industry's agenda, which hinders self-regulatory autonomy of communities and societal participation.
\end{abstract}

\section{Introduction: Biodiesel and Shales - between Good Governance and the Energy Leviathan}

The transition from traditional forms of government to governance arrangements that overcome top-down 'big government' structures and widen society participation on policy-making is not a simple task (Jordan, et al., 2005). The heterogeneity among institutions and the uneven distribution of power among stakeholders pose challenges to the enhancement of accountability and to the neutralization of mutual mistrust (Lemos \& Agrawal, 2009).

The discourse of sustainable development is ubiquitous in the energy sector, yet, complex power relations may turn governance arrangements into threats rather than opportunities (Verdonk, et al., 2007). As Nadaï et al. (2010 p.143) put it, "new energies bring new practices" - shifts in energy generation and in the control and use of resources do not necessarily lead to more transparency, accountability, and equity. Federalist systems are particularly complex, for private and public actors interact at multiple levels. Governance analysis, therefore, needs to address the ways that the regulatory framework flows across the political structure and how policy guidelines define arenas in which actors contend and reap their gains and losses.

The degree of 1) decentralization, 2) participation, 3) accountability, and 4) transparency indicates paths towards democratic governance and well-designed policies (Scheberle, 2004; Ribot, 2007). In the opposite direction, arrangements that fail on those parameters have the potential to render spurious governance arrangements (Gerber \& Kollman, | ${ }^{1} \mathrm{Ph} . D$. Environmental Sciences, Center for Sustainable Development (CDS), University of Brasília (UnB).

${ }^{1} \mathrm{Ph} . \mathrm{D}$. Political Science, University of Florida. Professor, University of Brasília, Coordinator, Postgraduate Program in Sustainable Development, Center of Sustainable Development. 
2004). In this paper we analyze how governance evolved along the four aforementioned axes in two emerging energy landscapes, the Eagle Ford Shale in the U.S. and the Gaucho Biodiesel Pole in Brazil.

Innovative resources such as biodiesel and shales increased their market share in the last decade, propelled as solutions to economic development, energy security and even as bridges to a clean energy transition (Lima \& Toni, 2017). Both resources involve specific political disputes that reflect what Hisschemöller, et al. (2001) called the knowledge, power, and participation game. This kind of game represents a challenge for the promotion of sound energy governance (Janssen \& Rutz, 2011; Rabe, 2014) for it may consolidate powerful elite regimes that foreclose pluralist forms of society participation in what we call the 'Energy Leviathan'?

\section{The Gaucho Biodiesel Poles \& Eagle Ford Shale}

The Gaucho Biodiesel Pole $(G B P)$ is the largest biodiesel energy landscape in Brazil. It is located in Brazil's third largest soybean production area (5.2 million hectares), where some 38,000 smallholders and 52,000 corporate farms supply nine biodiesel plants - three of the largest in the country- that account for $25 \%$ of Brazil's domestic biodiesel output (IBGE, 2017).

Several stakeholders and institutions are involved in the GBP governance: Large oilseed \& soy processing business groups, such as the Biodiesel Producers Association (Aprobio) and the Biodiesel and Biokerosene League (Ubrabio); grain traders; labor unions; farmer's associations and cooperatives; government agencies, particularly the Oil, Natural Gas, and Biofuels National Agency (ANP); and the giant state-controlled energy company Petrobras. The national biodiesel policy (PNPB) was conceived at the federal level to create innovative governance arrangements under the logic of the emerging biofuel economy (Maroun \& Larovere, 2008; Balis \& Baka, 2011). One of its main mechanism is a regulation that requires fuel dealers to blend biodiesel and mineral diesel. Official auctions guarantee biodiesel purchases from companies certified by the social fuel stamp (SFS) and offer subsidies in return for their purchasing of raw materials from smallholders and rural cooperatives. The social fuel stamp seeks to avoid the shortcomings of the ethanol policy, which fomented large-scale sugarcane plantations and precluded social participation. Policy-makers therefore tried to prevent a "bio-oil curse" and its negative outcomes on sustainable development (Hall, et al., 2009 p.584).

The Eagle Ford Shale (EFS) is one of the largest and most profitable unconventional hydrocarbon reserves in the U.S. Located in southern Texas, this energy landscape attracted huge investments (Dittrick, 2014) to develop terminals, plants and other facilities. Despite oil price drops that reduced the barrel to values under U\$40 in 2015, the volume of physical and financial capital still makes EFS one of the most exploited shales in the world (Hughes, 2015).

EFS governance includes a large number of social groups, market organizations and state

'The name of the biblical creature 'Leviathan' was used as the title of the book by Thomas Hobbes, published in 1651, as a symbol of the emergence of a powerful political authority that was able to control society. 
agencies: Leading U.S. oil and gas companies are represented by lobbies such as the Texas Oil \& Gas Association (Txoga) and the South Texas Energy Economic Roundtable (Steer). The Railroad Commission (RRC) and the Texas Commission on Environmental Quality (TCEQ) are regulatory agencies in charge of issuing permits and supervising energy production. In the legislative branch, the Natural Resources and Economic Development Committee, in the State Senate, and the Committee on Energy Resources, in the House of Representatives, have prerogatives to implement taxes and to define energy policies.

The development of fracking technologies to explore unconventional reserves caused a 'shale boom' in a region that had experienced a conventional oil peak in the early 1980s. This boom resulted in an increase of tax sales revenues but was not translated into economic diversification or improvements in public services and facilities. Civil society and city authorities therefore faced the challenge to consolidate long-term planning and to redefine their local ordinances on oil and gas exploitation in order to avoid another resource curse (Tunstall, 2015).

\section{Methods}

We reviewed the federalist structures of Brazil and the United States and their respective energy policies to understand the hierarchy and the formation of political arenas and the prerogatives of government agencies, commissions, committees, and chambers. We sought to comprehend power relations amongst state actors, civil society organizations, and businesses. We traveled across eight municipalities and conducted 35 interviews in the GBP in Rio Grande do Sul state between May and June, 2014. Interviewees included government officials, farmers, labor unions, cooperative CEOs, rural associations, and directors of biodiesel plants. In the EFS, Texas, we conducted 17 interviews in five counties, between January and February, 2015. Interviewees included city judges, city managers, chambers of commerce managers, city councilmen, and local businessmen. Representatives from the energy companies and regulatory agencies declined our requests for interviews. We also participated in a community meeting and a public hearing held to debate oil and gas ordinances.

We used the data to build a governance index for each energy landscape. This index is based on four sub-indices, which are composed by a subset of 11 weighted indicators, as follows: 1)decentralization: i) level of local government autonomy for energy regulation, ii) Other prerogatives delegated from central government; 2) participation: i) presence of committees, councils or public audiences, ii) involvement of civil organizations, iii) representativeness; 3)transparency and accountability: i) public access to technical and administrative data, ii) land planning iii) penalties and responsibility; and 4) equity: i) stakeholders' parity of rights over energy resources, ii) society's influence over energy regulation (layout \& implementation), iii) equity for applying revenues, fees and taxes.

We computed indicators in a two-step process: 1) we fed the primary data into a computer quality-data-assessment software and; 2) we rated the results in a Likert scale ranging from -2 (worst scenario) to +2 (better scenario). We present the results on Table 1 and Table 2. 


\section{Results}

\subsection{Brazilian Biodiesel Governance: Gaucho Biodiesel Poles (GBP)}

The National Council for Energy Policy (CNPE) and the Inter-ministerial Biodiesel Executive Commission (CEIB) - coordinated by the President's Chief of Staffare the main political arenas of the Brazilian biodiesel policy. An important policy arena is the Oil and Biodiesel Chamber, an advisory forum coordinated by the Ministry of Agriculture. Within the Chamber, members of the Brazilian Congress, government officials, and lobbyists interact to debate policy and regulations.

The policy layout does not decentralize authority nor delegates regulatory autonomy to states or local governments (Table 1- line1). Regional agencies in the state of Rio Grande do Sul, such as the Agro-energy Chamber and the Science Innovation and Technology Secretariat offer complementary incentives, but do not have autonomy to debate ordinances that deal with production, trade and use of biodiesel. Accordingly, municipal governments have no prerogatives and, at best, they can create friendly environments to attract businesses.

PNPB was designed to be an innovative multi-actor governance arrangement. It did share regulatory authority with federal agencies and defined economic incentives to bring biodiesel producers and farmers close together. The political arrangements however remained top-down and allowed further influence of resourceful stakeholders as Aprobio and Ubrabio, particularly through their congressional lobby (FrenteBio).

Table 1: Gaucho Biodiesel Poles (GBP) governance index

\begin{tabular}{|c|c|c|c|c|}
\hline \multirow[b]{2}{*}{ Governance sub-indices and indicators } & \multicolumn{4}{|c|}{ Calculation Method } \\
\hline & $\begin{array}{c}\text { Indices and } \\
\text { indicators } \\
\text { Weights }\end{array}$ & Qualitative & Quantitative & $\begin{array}{c}\text { Quantitative } \\
X \\
\text { Weight }\end{array}$ \\
\hline 1)Decentralization & 0,25 & & & $-0,40$ \\
\hline i)Local Government autonomy on energy regulation & 0,60 & $V U$ & -2 & $-1,2$ \\
\hline ii) Other prerogatives delegated from central government & 0,40 & $U$ & -1 & $-0,4$ \\
\hline Sub-total & 1,00 & & & $-1,6$ \\
\hline 2)Participation & 0,25 & & & $-0,25$ \\
\hline i)Committees, councils or public audiences & 0,50 & $U$ & -1 & $-1,0$ \\
\hline ii) Involvement of civil organizations & 0,25 & $F$ & 1 & 1,0 \\
\hline iii) Representativeness & 0,25 & $U$ & -1 & $-1,0$ \\
\hline Sub-total & 1,00 & & & $-1,0$ \\
\hline 3)Transparency \& Accountability & 0,25 & & & $-0,10$ \\
\hline i) Public access to technical and administrative data & 0,40 & $U$ & -1 & $-0,4$ \\
\hline ii)Land Planning & 0,30 & $N$ & 0 & 0,0 \\
\hline iii)Penalties and responsibility & 0,30 & $N$ & 0 & 0,0 \\
\hline Sub-total & 1,00 & & & $-0,4$ \\
\hline 4) Equity & 0,25 & & & $-0,36$ \\
\hline i) Stakeholders parity on distributive rights over energy resources & 0,40 & $U$ & -1 & $-0,4$ \\
\hline ii) Society's influence on energy regulation (layout \& implementation) & 0,35 & $U$ & -1 & $-0,35$ \\
\hline iii) Decision equity for applying energy revenues, fees and taxes & 0,35 & $V U$ & -2 & $-0,7$ \\
\hline Sub-total & 1,00 & & & $-1,45$ \\
\hline Total & & & & $-1,11$ \\
\hline
\end{tabular}

Legends: Very Favorable (VF); Favorable (F); Neutral (N); Very Unfavorable (VU); Unfavorable (U).

Source: elaborated by the authors. 
What policy makers have agreed to call participation (Table 1 - line2) within PNPB is restricted to the quotas offered to smallholders and their cooperatives in the grain supply chain. This 'market participation' did not promote voice and representativeness on biofuel development. Instead, it established the subordination of farmers to the large oilseed \& soy processing companies that reap federal subsidies under social fuel stamp certification. This rationality spreads among several other local stakeholders, as summarized by one of the cooperatives CEO's: "farmer's participation is limited to soy supply and it makes no difference to them what buyers do with the grain".

Although the policy was aimed at enhancing collaboration among social movements, cooperatives, biodiesel companies, and state institutions, it created fierce competition in the soybean trade and its valuable co-products. In this sense, the policy failed to create political awareness and community empowerment for it did not create local arenas to support public engagement in biodiesel regulation. In other words, biodiesel governance failed to expand the public domain (Ribot, 2007).

The lack of public channels to access data on biodiesel production reinforces community alienation. This lack of transparency (Table 1 - line 3) is potentially harmful (Tavares, 2014). Biodiesel is an organic and biodegradable fuel, but its industrial production demands significant use of chemicals and large amounts of water. Residues from the washing process are unsuitable to be discharged into water basins, but at least two leakages were reported at GBP (Rodrigues, 2014). Industrial accidents, including explosions, are also common in biodiesel plants, but disclosure is low for "the effect of this information on public opinion could damage the image that biodiesel has as an environmentally clean energy solution" (Juarez, 2011 p.1).

It is worth noting that biodiesel plants are subject to the federal environmental licensing regime. However, for the Ministry of the Environment, the main issue concerning biodiesel is the lack of an environmental-economic zoning for soybean plantations, similar to the one applied to the sugarcane/ethanol chain. Additionally, until 2016, only $10 \%$ of the rural properties in the state of Rio Grande do Sul complied with the Rural Environmental Registry law (CAR) and the 2012 Forest Code (Bayer, 2016).

The concentration of political arenas at the federal scale resulted in a very unfavorable equity framework concerning the distribution of benefits of biodiesel production (Table 1 - line4). This is worsened by the weakness of civil society in policy implementation, a process in which its role is restricted to legitimizing 'participants' in a regulatory game that adds little to the construction of a sound sustainable energy governance.

\subsection{Shale Governance in the US: the Eagle Ford Shale (EFS)}

The Energy Policy Act (EPACT), framed under the U.S. federalism, delegates broad competence in oil and gas production to the 50 states of the Union and grants a fair degree of autonomy to the local governments to define their own ordinances. Since the shale boom, however debates over decentralization vs. federalization and over local autonomy concerning energy regulation became highly controversial and a source of heated disputes all over the United States. In Texas, disagreements generated a political "powergrab" that redirected authority to state agencies. As a result, the majority of cities lost their prerogatives to define obstacles to fracking activities and to establish controls over companies and their accountability (Table $2-$ line 1$)$. 
The state Senate House Bill 40 (HB40), passed in 2015, curtailed local autonomy. Some civil associations considered that bill the funeral of community rights concerning energy regulation (Fig. 1). This turf war seems to be the result of a conflict between two groups. On one side, those who wish to ban fracking in urban areas (as in Denton city) and claim for deeper public debate on shale exploitation (College City Citizens for Safe Fracking). On the opposite side are those who, as phrased by a city manager we interviewed, defend that "local governments can't overreact and create problems for oil companies". HB40 was, therefore, a welcome solution for an industry that accounts for 40 percent of Texas economy (Stapleton, 2015).

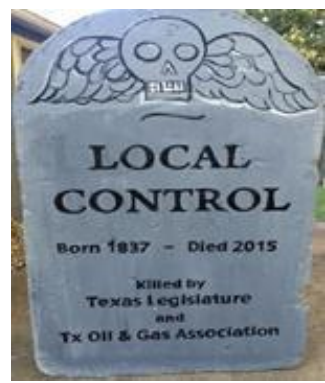

Figure 1: Local Control Tombstone. Lima (2016).

Table 2: Eagle Ford Shale (EFS) governance index

\begin{tabular}{|c|c|c|c|c|}
\hline \multirow[b]{2}{*}{ Governance sub-indices and indicators } & \multicolumn{4}{|c|}{ Calculation Method } \\
\hline & \begin{tabular}{|c|} 
Indices and \\
indicators \\
Weight
\end{tabular} & Qualitative & Quantitative & $\begin{array}{c}\text { Quantitative } \\
X \\
\text { Weight }\end{array}$ \\
\hline $\begin{array}{l}\text { 1)Decentralization } \\
\text { i)Local Government autonomy on energy regulation } \\
\text { ii) Other prerogatives delegated from central government } \\
\text { Sub-total }\end{array}$ & $\begin{array}{l}0,25 \\
0,60 \\
0,40 \\
1,00\end{array}$ & $\begin{array}{c}U \\
V U\end{array}$ & $\begin{array}{l}-1 \\
-2\end{array}$ & $\begin{array}{l}-0,35 \\
-0,6 \\
-0,8 \\
-1,4\end{array}$ \\
\hline $\begin{array}{l}\text { 2)Participation } \\
\text { i) Committees, councils or public audiences } \\
\text { ii) Involvement of civil organizations } \\
\text { iii) Representativeness } \\
\text { Sub-total }\end{array}$ & $\begin{array}{l}0,25 \\
0,50 \\
0,25 \\
0,25 \\
1,00\end{array}$ & $\begin{array}{l}U \\
U \\
U\end{array}$ & $\begin{array}{l}-1 \\
1 \\
-1\end{array}$ & $\begin{array}{l}-0,37 \\
-0,5 \\
-0,25 \\
-0,25 \\
-1,5\end{array}$ \\
\hline $\begin{array}{l}\text { 3) Transparency } \boldsymbol{\&} \text { Accountability } \\
\text { i) Public access to technical and administrative data } \\
\text { ii)Land Planning } \\
\text { iii)Penalties and responsibility } \\
\text { Sub-total }\end{array}$ & $\begin{array}{l}0,25 \\
0,40 \\
0,30 \\
0,30 \\
1,00\end{array}$ & $\begin{array}{l}U \\
U \\
F\end{array}$ & $\begin{array}{r}-1 \\
0 \\
0\end{array}$ & $\begin{array}{l}-0,10 \\
-0,4 \\
-0,3 \\
0,3 \\
-0,4\end{array}$ \\
\hline $\begin{array}{l}\text { 4) Equity } \\
\text { i) Stakeholders'parity on distributive rights over energy resources } \\
\text { ii) Society's influence on energy regulation (layout \& implementation) } \\
\text { iii) Decision equity for applying energy revenues, fees and taxes } \\
\text { Sub-total }\end{array}$ & $\begin{array}{l}0,25 \\
0,40 \\
0,35 \\
0,35 \\
1,00\end{array}$ & $\begin{array}{c}U \\
V U\end{array}$ & $\begin{array}{l}-1 \\
-2\end{array}$ & $\begin{array}{l}-0,36 \\
-0,4 \\
-0,35 \\
-0,7 \\
-1,45\end{array}$ \\
\hline Total & & & & $-1,18$ \\
\hline
\end{tabular}

Legends: Favorable (F), Very Favorable (VF), Neutral (N), Unfavorable (U), Very Unfavorable (VU).

Source: elaborated by the authors.

Lack of participation is a pattern in EFS. Even before HB40, few cities invited 
communities and the population at large to attend council meetings or public hearings (Table 2 - line 2). As highlighted by Williamson and Archon (2005), besides the American political tradition, US decision-makers are not compelled to respond to public demands. In EFS, local authorities reproduce oil and gas ordinances passed elsewhere, skirting proper public engagement. According to a city judge we interviewed, this means that "sometimes dictatorships are much easier to run than democracies". Powerful private interests represented by associations as Txoga, and Steer, joined with city managers, mayors, and development agencies to get laws passed in the Texas Legislature. Such legislation overturned public representativeness and embraced the new shale boom as an "answer to a prayer, the answer to a dream" (RRC, 2015, p.3).

The development of transparency and accountability mechanisms did not follow the fast spreading of ordinances (Table 2 - line 3), which was unfavorable for monitoring and controlling energy businesses. Penalties and responsibilities are defined by Texas legislation, but the lack of channels to access monitoring procedures, fines, and adjustment measures raised doubts about RRC commitment to have companies comply and reduce health, safety, and environmental externalities (Earthworks, 2012 and 2014).Critiques are addressed also to the Texas Commission on Environmental Quality (TECQ), which supposedly neglected threats to public health caused by leaks of volatile organic compounds and kept issuing permits that supported industry activities (Septof, 2013; Morris, et al., 2014a and 2014b).

The U.S. Environmental Protection Agency (EPA) has voiced its concern about the effectiveness of regulatory agencies in Texas. As a result, several lawsuits involving RRC, TECQ and EPA reached the courts. These contentions are expressed by the statement of one RRC commissioner who believes the agency's "job is to make sure industry produces efficiently and economically [...] and face federal overreach because Texans know how to oversee oil and gas production better than Washington does" (Malewitz, 2016,p.1). It is worth noting that until recently companies did not have to disclose data on disposals or chemical inputs used for hydraulic fracturing. This was one of the most controversial issues regarding loopholes on EPACT and it resulted in debates concerning the federalization of shale regulation (Davis \& Hoffer, 2012).

The recentralization of community prerogatives to Austin authorities resulted in a very unfavorable equity framework (Table 2 - line4). It reflects a considerably unbalanced relationship among different stakeholders and institutions that easily respond to industry demands, but shuts out further debates on the distribution of benefits from oil and gas exploitation (Matz, 2015).

\section{Discussion}

Regardless of the material differences between biodiesel and shale and the contrasting aspects of Brazilian and American federalism, in both cases results reveal poor performances $(-1,11$ and $-1,18$ respectively) that indicate spurious governance systems. The main reason is related to the particularities of arenas, stakeholders, and policies, which, instead of promoting innovative and balanced relationships among state, society, and private actors, has been captured by the hegemonic values of the most resourceful stakeholders. Despite the differences in energy policies - one excessively 
centralized and other largely decentralized -, without due attention to participatory mechanisms and equity parameters, both systems are doomed to fail.

The indicators we applied show that both Brazilian biodiesel governance and U.S. shale governance failed to provide or maintain mechanisms of participation and representativeness that could counter-balance the interests and powers of an elite linked to these new energy resources. PNPB guidelines, for example, did not break away from traditional top-down structures and caused negative outcomes to biofuels production as the ethanol policy - once biodiesel political arrangements fell under control of elite stakeholders. Its activities also (re)stimulated the spread of large monocultures (such as soybeans) as the main raw material. The North American shale governance at Texas in turn developed a throwback towards big-government rationality that abruptly changes game rules and curtails the historical autonomy of local control arenas and indulges the powerful interests of the traditional oil and gas sector.

Additionally, the parameters we applied showed little transparency in the governance mechanism in both energy landscapes. Channels of public access are absent. In both cases these conditions contributed to the high level of societal exclusion that reduced pressures on companies' accountability regarding social and environmental damages. The set of ordinances, bills, and policies we analyzed in GBP and EFS shows a neglect of precautionary principles, norms, and rules aimed at controlling the risks inherent to shale exploitation, as well as to manage the externalities of biodiesel production.

\section{Conclusion}

In this paper we analyzed power relations amongst state actors, civil society organizations, and businesses in two energy landscapes, the Gaucho Biodiesel Pole in Brazil and the Eagle Ford Shale in the U.S. We presented a governance index for each energy landscape, based on four sub-indices and a subset of 11 indicators. In both cases the governance index was similarly low. What lies behind such disappointing governance mechanisms is the development of severe asymmetries derived from alignments between key policy makers and the resourceful energy stakeholders. Those alliances overshadow public interest and pre-empt broad social representation.

Further research is necessary to detect whether the same flaws persist in other energy landscapes and their respective governance arrangements. Nonetheless, in both cases examined here, energy businesses have become so strong and pervasive in their influence and strategies over government structures, arenas, and policy controls that they shut out pluralist forms of democratic governance. This resulted in the formation of powerful elite regimes, or Energy Leviathans.

\section{References}

Bailis, R.; Baka, J. (2011). Constructing Sustainable Biofuels: Governance of the Emerging Biofuel Economy. Annals of the Association of American Geographers, 101(04) 827-838.doi: 10.1080/00045608.2011.568867

Bayer, L. (2016). Subcomissão para tratar da implantação do Cadastro Ambiental Rural (CAR). Assembléia Legislativa do Rio Grande do Sul. 66pp. 
Davis, C.; Hoffer, K.. (2012). Federalizing energy? Agenda change and the politics of fracking. Policy Sci, (45) 221-241. doi: 10.1007/s11077-012-9156-8

Dittrick, P. W. (2014). Eagle Ford 2013 spending to reach U\$ 23 billion. Oil \& Gas Journal, (110) 12-13.

Earthworks. (2012).Enforcement Report RRC. Texas Railroad Commission: Inadequate enforcement means irresponsible oil and gas development. Retrieved from: http://www.earthworksaction.org/ /texasoilgasenforcementhepublicsrole.

Earthworks. (2014). Texas Oil \& Gas Enforcement- Public Participation. Citizen Complaints help uncover violations. Retrieved from: www.earthworksaction.org/issue/detail/texasoilgasenforcementthepublicsrole.

Gerber, E. R., \& Kollman, K. (2004). Authority migration: Defining an emerging research agenda. Political Science and Politics, 37(3) 397-401.doi: 10.1017/S104909650400455X

Hall, J.; Matos, S.; Severino, L.; Beltrão, N. (2009). Brazilian biofuels and social exclusion: established and concentrated ethanol versus emerging and dispersed biodiesel. Journal of Cleaner Production, (17) 577 585.doi:10.1016/j.jclepro.2009.01.003

Hisschemöller, M.; Hoppe, R.; Dunn, W.N.; Ravetz, J.R. (2001). Knowledge, Power and Participation in Environmental Policy Analysis. Policy Studies Review Annual, (12) Transaction Publishers, New Brunswick, New Jersey, 527p.

Hughes, J.D. (2015). Eagle Ford Reality Check: The Nation's top tight oil play after more than a year of low oil prices. Post Carbon Institute, California.

IBGE. (2017). Instituto Brasileiro de Geografia e Estatística. Censo Agropecuário de 2017. Retrieved from: https://censos.ibge.gov.br/agro/2017/

Janssen, R; Rutz, D. D. (2011).Sustainability of biofuels in Latin America: Risks and opportunities. Energy Policy, (39) 5717-5725.doi:10.1016/j.enpol.2011.01.047

Jordan, A.; Wurzel, R. K. W.; Zito, A. (2005) The rise of 'new' policy instruments in comparative perspective: Has governance eclipsed government? Political Studies, 53(3) 477-96. Doi:10.1111/j.14679248.2005 .00540

Juarez, P. (2011). Explosões em usinas de biodiesel: o que fazer? BiodieselBR. July. Retrieved from: www.biodieselbr.com/revista/023/coluna-paulo-suarez.htm.

Lemos, M. C.; Agrawal, A. (2009). Environmental governance. Annual Review of Environment and Resources, (31) 297-325.doi: 10.1146/annurev.energy.31.042605.135621

Lima, A.; (2016). Eco-governamentalidade e Governança de Recursos Energéticos: entre a prática e o discurso na ação coletiva dos Polos Gaúchos de biodiesel e dos folhelhos texanos de Eagle Ford Shale. Doctoral dissertation, Sustainable Development, Center for Sustainable Development (CDS), University of Brasília, Brasília, Brazil.

Lima, A.; Toni, F. (2017). Energy Landscapes and Environmentality: Boundaries between Discourses and Practices in Energy Governance. IJESD, 8(09) 673-677. doi: 10.18178/ijesd.2017.8.9.1036

Malewitz, J. (2016). Environmentalists Ask EPA to Strip Texas Authority. Texas Tribune Digital Nens. January 12, 2016. Retrieved from:www.texastribune.org/plus/water/vol-4/no-1/environmentalists-askepa-strip-texas-authority.

Maroun, M. R.; Larovere, E. L. (2008). Ethanol and food production by family smallholdings in rural Brazil: Economic and socio-environmental analysis of micro distilleries in State of Rio Grande do Sul. Biomass and Bioenergy, 18(04) 885-98. doi: 10.1016/j.biombioe.2014.02.023

Matz, J.; Renfrew, D. (2015). Selling "Fracking": Energy in Depth and the Marcellus Shale. Environmental Communication, 9(3) 288-306.doi: 10.1080/17524032.2014.929157

Morris. J; Song, L; Hasemyer, D. (2014). Fracking boom spews toxic air emissions on Texas residents. Pittsburg Post-Gazette, February 25, 2014. Retrieved from: www.postgazette.com/powersource/latest-oil-and-gas/2014/02/25/

Morris. J; Song, L; Hasemyer, D. Big Oil, Bad Air: Fracking the Eagle Ford Shale of South Texas. The Centre of Public Integrity, February 18, 2014. Retrieved from:: http:// eagleford.publicintegrity.org.

Nadaï, A.; Van Der Horst, D. (2010). Introduction: Landscapes of Energies. Landscape Research, 35(02) 143155. DOI: $10.1080 / 01426390903557543$

Rabe, B. (2014). Governance concerns and government capacity to shale gas. In: Stern, P.C. (Org.) Risks and Risk. Governance in Shale Gas Development. (1663-1692). Washington,: The National Academy Press.

Ribot, J. C. (2007). Representation, Citizenship and the Public Domain in Democratic Decentralization. Development, 50(1), 43-49. doi: 10.1057/palgrave.development.1100335

Rodrigues, F. (2014).Com os pés no chão. BiodieselBR, 7(42) 09-11. 
RRC. (2015).Railroad Commission of Texas. Eagle Ford Shale Task Force. Report. Austin, 2013. Retrieved from: www.rrc.state.tx.us/media/30156/final-self-evaluation-report-2015.pdf.

Stapleton, S. (2015). Texas pushes forward bill that would ban fracking ban. Reuters, April 18. Retrieved from: https://www.rt.com/usa/250797-texas-bill-bans-fracking prohibit/.

Septof, A. (2013). Fracking the Eagle Ford - TCQE's nondenial. Earthworksaction.org, September 30. Retrieved from:www.earthworksaction.org/issue//frackingtheeaglefordtceqsnondenial.

Scheberle, D. (2004).Federalism and environmental policy: Trust and the politics of implementation. (2nd ed.)Washington: Georgetown University Press

Tavares, J. (2014). Bomba Relógio. BiodieselBR, 06(40)52-55.

Tunstall, T. (2015). Recent Economic and Community Impact of Unconventional Oil and Gas Exploration and Production on South Texas in the Eagle Ford Shale. The Journal of Regional Analysis \& Policy 45(01) 82-92.

Verdonk, M.; Dieperink, C.; Faaij, A. (2007). Governance of the emerging bio-energy markets. Energy Policy, (35) 3909-3924. doi:10.1016/j.enpol.2006.12.028

Williamson, A.; Archon, F. (2004). Political Deliberation: Where We Are and Where We Can Go. National Civic Review, (01) 03-15. 